\title{
GAMBARAN KEJADIAN TUBERKULOSIS DI KABUPATEN PATI
}

\section{INCIDENT DESCRIPTION OF TUBERCULOSIS IN PATI REGENCY}

\author{
Dwi Murtono \\ Rumah Sakit Daerah Kayen Kabupaten Pati \\ Email : dwi_murt@yahoo.com
}

Naskah Masuk: 30 September 2017 Naskah Revisi: 10 Oktober 2017 Naskah Diterima: 17 Oktober 2017

\begin{abstract}
Tuberculosis is one of the long-known diseases and still becomes the leading cause of death in the world. The TB incidence needs a serious attention because it is a major public health problem. The objective of the study was to describe the TB incidence in Pati Regency in the period 2014-2016. It used quantitative and descriptive approaches. Secondary data sourced from Integrated Tuberculosis Information System (SITT) period 2014-2016 at Health Service of Pati Regency. Data were classified based on sex, TB classification, and age. Data were tested using descriptive analysis. The results of the study were: (1) The TB incidence showed an increase, (2) The increase of TB incidence was found both in men and women, but the number of TB cases was higher in men compared to the counterparts. (3) The number of TB cases increased in all TB classification groups, which the highest was found in positive smear pulmonary group. (4) The number of TB cases rose along with the increase of age, which the majority cases occurred in the productive age group.
\end{abstract}

Keywords: age, sex, TB clasification, tuberculosis.

\begin{abstract}
ABSTRAK
Tuberkulosis (TB) merupakan salah satu penyakit yang telah lama dikenal dan sampai saat ini masih menjadi penyebab utama kematian di dunia. Kejadian TB perlu mendapat perhatian serius karena TB merupakan masalah kesehatan publik mayor. Tujuan penelitian ini adalah untuk memberikan gambaran kejadian TB di Kabupaten Pati dalam kurun waktu tahun 2014-2016. Penelitian ini menggunakan pendekatan deskriptif kuantitatif. Data sekunder berasal dari Sistem Informasi Tuberculosis Terpadu (SITT) Kabupaten Pati tahun 2014-2016 dari Dinas Kesehatan Kabupaten Pati. Data diolah berdasarkan jenis kelamin, klasifikasi TB dan umur penderita TB. Analisis data dilakukan secara deskriptif. Hasil penelitian adalah (1) angka kejadian TB menunjukkan adanya peningkatan; (2) angka kejadian TB berdasarkan klasifikasi jenis kelamin lebih banyak ditemukan pada jenis kelamin laki-laki dan menunjukkan terjadi peningkatan kejadian TB baik untuk laki-laki maupun perempuan; (3) angka kejadian TB berdasarkan klasifikasi TB secara umum menunjukkan terjadi peningkatan dan mayoritas kejadian adalah TB paru BTA positif; (4) kejadian TB mengalami peningkatan seiring dengan bertambahnya umur. Secara umum, kejadian TB paling besar terjadi pada usia produktif.
\end{abstract}

Kata kunci : umur, jenis kelamin, klasifikasi TB, tuberkulosis 


\section{PENDAHULUAN}

Tuberkulosis (TB) merupakan salah satu penyakit yang telah lama dikenal dan sampai saat ini masih menjadi penyebab utama kematian di dunia (Saptawati dkk, 2012). WHO memperkirakan setiap tahun masih terdapat sekitar sembilan juta penderita TB paru baru dengan kematian sekitar 1,1 sampai 1,6 juta orang termasuk kasus TB dengan HIV positif (WHO, 2011). Berdasarkan data WHO sampai tahun 2008, penyakit TB masih menjadi pembunuh nomor dua di dunia dari seluruh penyakit infeksi setelah HIV yang diperkirakan telah membunuh 1,8 juta (WHO, 2009). Diperkirakan sepertiga penduduk dunia sudah terinfeksi kuman Mycobacterium tuberculosis secara laten.

Dekade terakhir, kejadian TB sangat meningkat di Afrika terutama sebagai akibat dari meningkatnya beban infeksi HIV, sedangkan di Uni Soviet karena faktor perubahan sosial ekonomi dan penurunan sistem perawatan kesehatan (WHO, 2004). TB merupakan penyakit yang erat hubungannya dengan sosial ekonomi. Pendapatan yang rendah dengan jumlah keluarga yang besar dan hidup di lingkungan padat dengan sanitasi perumahan yang buruk, mempunyai kemungkinan yang lebih tinggi untuk terinfeksi kuman TB dan berkembang menjadi sakit TB serta kemungkinan akan meninggal karena TB (WHO, 2004).

Tahun 2010 sebanyak 6,2 juta orang di dunia telah didiagnosis menderita TB yang terdiri dari 5,4 juta kasus baru, 300.000 kasus kambuh dan 400.000 pengobatan ulang. Negaranegara yang memiliki beban tinggi penyakit TB (high burden countries) sebanyak 22 negara termasuk Indonesia menyumbang sekitar $82 \%$ penderita TB dunia. Kasus TB di dunia menurut laporan WHO tahun 2010, total kasus baru BTA positif sebanyak 2.591.032 dengan proporsi pada laki-laki lebih tinggi dibandingkan pada wanita yaitu sebesar 65\% (Rab, 2013).

Asia Tenggara tahun 2010 angka prevalensi mencapai 5 juta per tahun dan angka insiden 3,5 juta. Kebanyakan kasus terjadi pada kelompok usia 15-54 tahun, dan menurut jenis kelamin lakilaki lebih banyak kasus dibandingkan wanita dengan rasio 2:1 (Djoerban dan Djauzi, 2014). Tahun 2011 menurut WHO, setengah dari jumlah penderita TB di dunia berada di kawasan Asia Tenggara dan setiap tahunnya terdapat 500.000 orang di kawasan ini meninggal akibat penyakit TB paru (Djoerban dan Djauzi, 2014). Mortalitas dan morbiditas meningkat sesuai dengan bertambahnya umur. Angka kesakitan (morbidity) tuberkulosis lebih tinggi di antara penduduk miskin dan daerah perkotaan jika dibandingkan dengan daerah pedesaan (Darmawansyah, 2016).

Indonesia menurut WHO pada tahun 2011 jumlah insiden kasus TB paru sebesar 222 per 1000.000 penduduk, prevalensi sebesar 489 per 100.000 penduduk dan kematian sebesar 48 per 100.000 penduduk (Rab, 2013). Tahun 2012, insiden kasus TB paru menduduki peringkat keempat di dunia. Kasus TB di Indonesia tahun 2011 tercatat sebanyak 316.562 kasus dengan kasus berdasarkan jenis kelamin adalah 182.853 kasus $(57,8 \%)$ pada pria dan 133.709 kasus $(42,2 \%)$ pada wanita. Khusus kasus TB BTA positif tahun 2011 tercatat 194.780 kasus, sebanyak 115.450 kasus $(59,3 \%)$ pada pria dan 79.330 kasus $(40,7 \%)$ pada wanita (Rab, 2013). 
Kasus TB di Jawa Tengah yang tercatat tahun 2011 sebanyak 39.238 kasus dengan 21.589 kasus $(55 \%)$ pada pria dan 17.649 kasus $(45 \%)$ pada wanita. Berdasarkan data angka penemuan kasus TB yang ternotifikasi di provinsi Jawa Tengah tahun 2016, Kota magelang berada di peringkat pertama dengan 922 kasus/100.000 penduduk, disusul oleh Kota Salatiga dengan 333 kasus/100.000 penduduk dan Kota Surakarta dengan 293 kasus/100.000 penduduk. Kabupaten Pati, angka temuan kasus TB yang ternotifikasi adalah 68 kasus/100.000 penduduk. Jika dibandingkan dengan target yang ditetapkan oleh Provinsi Jawa Tengah yaitu 118 kasus/100.000 penduduk, Kabupaten Pati belum mencapai target yang ditetapkan oleh Provinsi Jawa Tengah. Namun demikian, kejadian TB perlu mendapat perhatian serius karena TB merupakan masalah kesehatan publik mayor (Guo et al, 2009). TB yang menyerang paru dapat menurunkan fungsi pengembangan paru akibat perubahan fibrosis paru difus. Hal tersebut akan mengakibatkan pasien dengan TB paru mengalami gangguan pertukaran gas, sehingga menurunkan kapasitas fungsional (Sivaranjini et al, 2010).

Berdasarkan latar belakang tersebut, maka tujuan penelitian ini adalah untuk memberikan gambaran kejadian TB di Kabupaten Pati berdasarkan jenis kelamin, klasifikasi dan umur dalam kurun waktu tahun 2014-2016.

\section{TINJAUAN PUSTAKA}

\section{Pengertian Tuberkulosis (TB)}

TB adalah penyakit infeksi yang disebabkan oleh Mycobacterium tuberculosis yang ditemukan pada dahak pasien dengan penyakit TB paru (Barker, 2012). Basil ini bersifat aerob tahan asam yang mampu membentuk spora dalam jaringan beroksigen tinggi (Lawn dan Zumla, 2011). Mycobacterium tuberculosis yang menyebabkan penyakit TB adalah Mycobacterium tuberculosis gen $\mathrm{H}_{37} \mathrm{RV}$. Basil ini merupakan yang paling pathogen dan mempunyai kemampuan untuk berkembang dan yang paling penting adalah kemampuannya untuk tetap bertahan hidup bertahuntahun di dalam tubuh tuan rumahnya (Meena, 2010).

Mycobacterium tuberculosis mempunyai ukuran \pm 0,5-4 mikron x 0,30,6 mikron dengan bentuk batang tipis, lurus atau agak bengkok, bergranular atau tidak mempunyai selubung, tetapi mempunyai lapisan luar tebal yang terdiri dari lipoid (terutama asam mikolat). Mycobacterium tuberculosis dapat bertahan terhadap pencucian warna dengan asam dan alkohol, sehingga disebut Basil Tahan Asam (BTA), tahan terhadap zat kimia dan fisik serta tahan dalam keadaan kering dan dingin, bersifat dorman dan aerob (Widoyono, 2008).

\section{Klasifikasi TB}

a. Klasifikasi berdasarkan organ tubuh yang terkena menyerang jaringan paru, tidak termasuk pleura (selaput paru)
(1). TB Paru adalah TB yang
(2). TB Ekstra Paru adalah TB yang menyerang organ tubuh lain selain paru, misalnya pleura, selaput otak, selaput jantung, kelenjar limfe, tulang, persendian, kulit, usus, ginjal, saluran kencing, alat kelamin dan lain-lain.


b. Klasifikasi berdasarkan hasil pemeriksaan dahak mikroskopik pada TB paru

(1). TB Paru BTA Positif, sekurangkurangnya 2 dari 3 spesimen dahak SPS hasilnya BTA (+), 1 spesimen dahak SPS hasilnya BTA (+) dan foto toraks dada menunjukkan gambaran TB, 1 spesimen dahak SPS hasilnya BTA (+) dan biakan kuman TB positif, 1 atau lebih spesimen dahak hasilnya positif setelah 3 spesimen dahak SPS pada pemeriksaan sebelumnya hasilnya BTA negatif dan tidak ada perbaikan setelah pemberian antibiotika non OAT.

(2). TB Paru BTA negatif, kriteria diagnosis TB paru BTA negatif harus meliputi : paling tidak 3 spesimen dahak SPS hasilnya BTA negatif, foto toraks abnormal menunjukkan gambaran TB, tidak ada perbaikan setelah pemberian antibiotik non OAT, ditemukan (dipertimbangkan) oleh dokter untuk diberi pengobatan.

(Muaz, 2014)

\section{Faktor Risiko Terjadinya TB}

Sumber penularan adalah pasien TB BTA positif pada waktu batuk atau bersin, pasien menyebarkan kuman ke udara dalam bentuk percikan dahak (droplet nuclei). Sekali batuk dapat menghasilkan sekitar 3.000 percikan dahak. Daya penularan seorang pasien ditentukan oleh banyaknya kuman yang dikeluarkan dari parunya. Makin tinggi derajat kepositifan hasil pemeriksaan dahak, makin menular pasien tersebut. Faktor yang memungkinkan seseorang terpajan kuman TB ditentukan oleh konsentrasi percikan dalam udara dan lamanya menghirup udara tersebut (Kemenkes RI, 2011).

Risiko seseorang yang terinfeksi kuman TB hanya sekitar 10\% akan menjadi sakit TB. Annual Risk of Tuberculosis Infection (ARTI) yaitu proporsi penduduk yang berisiko terinfeksi TB selama satu tahun sebesar $1 \%$, diperkirakan diantara 100.000 penduduk rata-rata 1.000 orang terinfeksi TB dan 10\% diantaranya (100 orang) akan menjadi sakit TB setiap tahun. Sekitar 50 diantaranya adalah pasien TB BTA positif sisanya menderita TB BTA negatif rontgen positif, ekstra paru, TB kelenjar, TB kulit, TB tulang dan lainlain (Kemenkes RI, 2011).

Sumber infeksi penyakit TB paru diantaranya adalah kontak dengan penderita TB BTA positif (Darmawansyah, 2016). Faktor lainnya yang berpengaruh adalah usia, jenis kelamin, gizi, merokok, kemiskinan, kesehatan lingkungan, ras, serta vaksinasi BCG. Faktor risiko yang mempengaruhi terjadinya TB adalah jenis kelamin pria, non-hispanik ras kulit hitam, usia yang lebih muda, tuna wisma, penggunaan alkohol, atau penggunaan narkoba suntikan dalam masa 12 bulan lalu, HIVpositif, penyakit cavitary, dan kontak dengan penderita BTA positif (Talarico et al, 2011).

Faktor risiko TB yang penting pada tingkat populasi adalah kemiskinan, pekerjaan yang berhubungan dengan risiko tinggi penularan $\mathrm{TB}$, dan faktorfaktor yang merusak daya tahan tubuh terhadap infeksi TB dan penyakit, seperti infeksi HIV, kekurangan gizi, merokok, diabetes, penyalahgunaan alkohol, dan polusi udara dalam ruangan (Lönnroth et al, 2009). 


\section{METODE PENELITIAN}

Penelitian ini menggunakan pendekatan deskriptif kuantitatif. Data berupa data sekunder yaitu data dari Sistem Informasi Tuberculosis Terpadu (SITT) Kabupaten Pati tahun 2014 sampai tahun 2016 yang diperoleh dari Dinas Kesehatan Kabupaten Pati. Data diolah berdasarkan jenis kelamin, klasifikasi TB dan umur penderita TB. Analisis data dilakukan secara deskriptif.

\section{HASIL DAN PEMBAHASAN}

\section{Angka Kejadian TB di Kabupaten Pati}

Angka kejadian TB di Kabupaten Pati dalam 3 tahun terakhir (tahun 20142016) menunjukkan adanya kecenderungan terjadi peningkatan. Kejadian TB pada tahun 2014 yaitu 736 kejadian, tahun 2015 meningkat menjadi 949 kejadian atau bertambah 28,94\% dibandingkan pada tahun 2014. Untuk tahun 2016, kejadian TB yaitu 963 kejadian atau meningkat sebesar 1,48\% dibandingkan tahun 2015. Grafik angka kejadian TB di Kabupaten Pati tahun 2014-2016 disajikan pada Gambar 1.

Beberapa faktor yang mempengaruhi kemungkinan seseorang menjadi pasien TB menurut Depkes RI
(2007) adalah daya tahan tubuh yang rendah, di antaranya infeksi HIV/AIDS dan malnutrisi (gizi buruk), faktor lingkungan yaitu ventilasi, kepadatan hunian, faktor perilaku, kesehatan perumahan, lama kontak dan kosentrasi kuman. Penelitian yang dilakukan oleh Rukmini dan Chatarina (2011) menyebutkan bahwa faktor risiko TB yang berpengaruh secara signifikan terhadap kejadian TB paru dewasa di Indonesia adalah umur, jenis kelamin, energi penerangan, tindakan buka jendela kamar, status gizi dan kontak serumah TB. Adapun faktor risiko yang paling dominan terhadap kejadian TB paru dewasa adalah kontak serumah dengan penderita TB. Sedangkan dalam penelitian Kurniasari dkk (2012) menyebutkan bahwa faktor yang terbukti berpengaruh terhadap kejadian tuberkulosis paru adalah kondisi sosial ekonomi, pencahayaan ruangan, dan luas ventilasi. Faktor yang tidak terbukti adalah kepadatan hunian, kelembaban hunian, suhu ruangan, riwayat kontak penderita dalam satu rumah, pengetahuan responden tentang tuberkulosis, sikap responden tentang tuberkulosis, dan kebiasaan merokok.

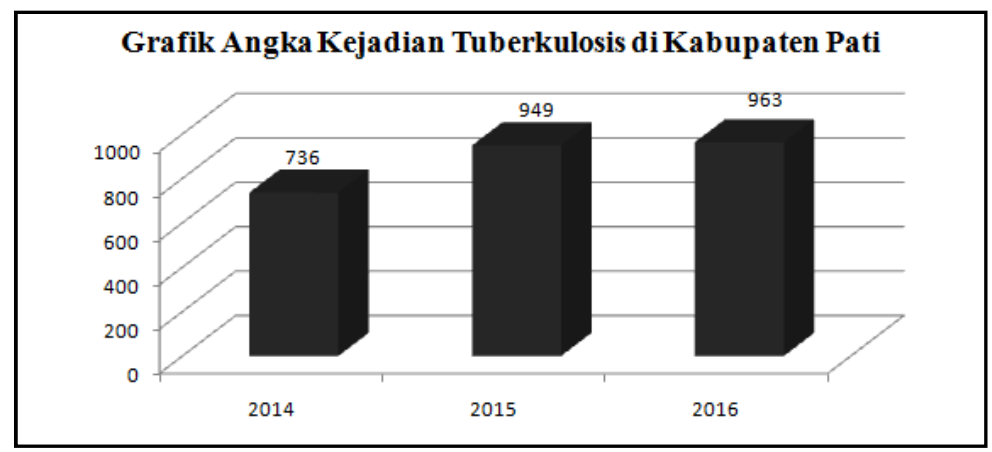

Gambar 1.

Angka Kejadian TB di Kabupaten Pati Tahun 2014-2016

Sumber : Dinkes Kab.Pati (2014-2016) 


\section{Angka Kejadian TB di Kabupaten Pati Berdasarkan Jenis Kelamin}

Kejadian TB dialami baik oleh laki-laki maupun perempuan. Angka kejadian TB di Kabupaten Pati berdasarkan jenis kelamin tahun 20142016 disajikan pada Gambar 2. Gambar 2 menunjukkan bahwa terjadi peningkatan kejadian TB baik untuk laki-laki maupun perempuan. Tahun 2014, kejadian TB pada laki-laki adalah 437 kejadian dan perempuan adalah 299 kejadian. Tahun 2015, kejadian TB pada laki-laki meningkat $29,75 \%$ menjadi 567 kejadian, sedangkan kejadian TB untuk perempuan pada tahun 2015 mengalami peningkatan sebesar 27,76\% menjadi 382 kejadian. Untuk tahun 2016, kejadian TB pada laki-laki mengalami penurunan sebesar 0,71 menjadi 563 kejadian, sedangkan kejadian TB pada perempuan meningkat sebesar $4,71 \%$ menjadi 400 kejadian.

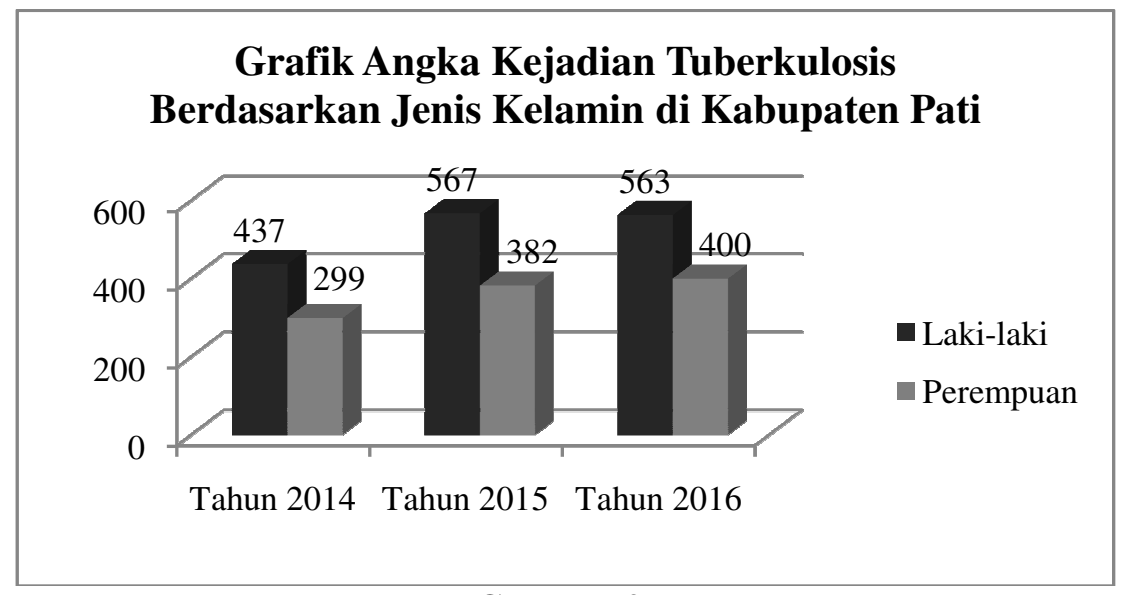

Gambar 2.

Angka Kejadian TB di Kabupaten Pati Berdasarkan Jenis Kelamin

Tahun 2014-2016

Sumber : Dinkes Kab.Pati (2014-2016)

Menurut Crofton et al dalam Purnamasari (2010), angka kejadian TB pada pria selalu cukup tinggi pada semua usia tetapi pada wanita cenderung menurun tajam sesudah melampui usia subur. Wanita prevalensi TB mencapai maksimum pada usia 40-50 tahun dan kemudian berkurang, sedangkan pada pria prevalensi terus meningkat sampai sekurang-kurangnya mencapai usia 60 tahun. Menurut Dye dalam Zaman (2010) pria lebih sering terkena TB daripada wanita. Kasus TB di sebagian besar negara lebih tinggi pada pria daripada wanita. Rasio wanita terhadap kasus TB laki-laki dilaporkan secara global adalah
0,47 : 0,67 . Penyebab perbedaan prevalensi TB berdasarkan jenis kelamin, belum dapat dipastikan. Perbedaan ini kemungkinan disebabkan oleh adanya perbedaan dalam faktor risiko infeksi, tingkat perkembangan dari infeksi menjadi penyakit, rendahnya pelaporan kasus TB pada wanita, atau perbedaan akses pelayanan.

Pendapat yang sama juga dikemukakan oleh Zeana and El-Sadr (2004) yang menyatakan bahwa perbedaan prevalensi TB berdasarkan gender secara global belum diketahui penyebab pastinya. Hipotesis utama untuk menjelaskan perbedaan ini adalah 
perbedaan yang muncul karena betulbetul karena gender. Perbedaan gender terkait dengan faktor biologis terhadap reaksi infeksi Mycobacterium tuberculosis untuk berkembang menjadi penyakit aktif. Faktor lainnya adalah sosial budaya dapat mempengaruhi kesempatan untuk terpapar Mycobacterium tuberculosis serta kondisi yang mendorong perkembangan penyakit dan reaktivasi. Hipotesis kedua adalah bahwa terjadi underdiagnosis dan tidak dilaporkannya TB pada wanita, terutama di negara-negara berpenghasilan rendah. Berbagai faktor, termasuk citra diri, status dalam keluarga dan masyarakat, akses terhadap sumber daya kesehatan, dan manifestasi dan ekspresi dari stigma yang terkait dengan TB, dapat mempengaruhi perilaku pencarian perawatan pada wanita.

Selain itu, hasil penelitian Datulong dkk (2015) juga menyebutkan bahwa laki-laki beresiko lebih besar untuk terkena penyakit TB paru dibandingkan dengan perempuan. Lakilaki lebih banyak yang merokok dan minum alkohol dibandingkan dengan perempuan. Merokok dan minum alkohol dapat menurunkan imunitas tubuh sehingga lebih mudah terkena penyakit TB paru.

\section{Angka Kejadian TB di Kabupaten Pati Berdasarkan Klasifikasi TB}

Klasifikasi TB berdasarkan organ tubuh yang terkena dibagi menjadi TB paru dan TB ekstra paru. Sedangkan TB paru diklasifikasikan lagi berdasarkan hasil pemeriksaan dahak mikroskopik pada TB paru dibagi menjadi TB paru BTA+ dan TB paru BTA-. Angka kejadian TB di Kabupaten Pati berdasarkan klasifikasi TB tahun 20142016 disajikan pada Gambar 3. Tahun 2014, kejadian TB paru untuk BTA+ adalah 460 kejadian dan BTA- adalah 203 kejadian, kejadian TB ekstra paru adalah 7 kejadian, sedangkan BTA tidak diperiksa adalah 66 kejadian. Pada tahun 2015, terjadi peningkatan 22,39\% untuk BTA+ menjadi 563 kejadian dan meningkat $44,83 \%$ untuk BTA- menjadi 294 kejadian.

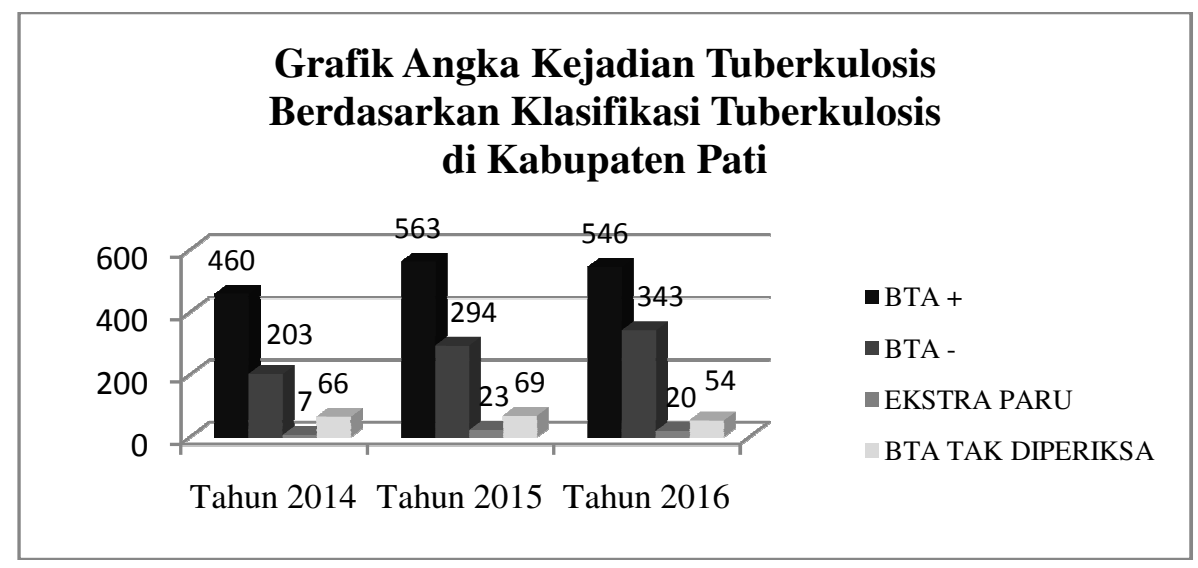

\section{Gambar 3.}

Angka Kejadian TB di Kabupaten Pati Berdasarkan Klasifikasi TB

Tahun 2014-2016

Sumber : Dinkes Kab.Pati (2014-2016) 
TB ekstra paru juga terjadi peningkatan sebesar $228,57 \%$ menjadi 23 kejadian. Sedangkan untuk TB yang BTA tidak diperiksa mengalami peningkatan sebesar $4,55 \%$ menjadi 69 kejadian. Selanjutnya pada tahun 2016, untuk TB paru dengan BTA+ mengalami penurunan sebesar $-3,03 \%$ menjadi 546 kejadian. Sedangkan untuk TB paru BTA- mengalami peningkatan sebesar $16,67 \%$ menjadi 343 kejadian. TB ekspra paru kejadiannya mengalami penurunan sebesar 13,04\% menjadi 20 kejadian. Demikian juga dengan TB yang BTA tidak diperiksa mengalami penurunan kejadian sebesar 21,74\% menjdai 54 kejadian.

TB yang dapat menjadi sumber penularan adalah TB BTA positif. Gambar 3 menunjukkan bahwa kejadian TB BTA+ merupakan kejadian tertinggi di Kabupaten Pati sehingga memiliki potensi penularan TB yang relatif besar. Indonesia, tahun 2013 ditemukan jumlah kasus baru Bakteri Tahan Asam (BTA) positif (BTA+) sebanyak 196.310 kasus, menurun bila dibandingkan kasus baru BTA+ yang ditemukan tahun 2012 yang sebesar 202.301 kasus. Jumlah kasus tertinggi yang dilaporkan terdapat di provinsi dengan jumlah penduduk yang besar yaitu Jawa Barat, Jawa Timur, dan Jawa Tengah. Kasus baru BTA+ di tiga provinsi tersebut hampir sebesar $40 \%$ dari jumlah seluruh kasus baru di Indonesia. Menurut jenis kelamin, kasus BTA+ pada laki-laki lebih tinggi daripada perempuan yaitu hampir 1,5 kali dibandingkan kasus BTA+ pada perempuan. Pada masing-masing provinsi di seluruh Indonesia kasus BTA+ lebih banyak terjadi pada laki-laki dibandingkan perempuan (Depkes RI dalam Dotulong dkk, 2015).

Hasil penelitian Muaz (2014) tentang faktor yang mempengaruhi kejadian TB paru BTA+ dengan studi di
Puskesmas wilayah Kecamatan Serang Kota Serang menyimpulkan bahwa (1) faktor yang paling berisiko meningkatkan angka kejadian penyakit TB paru BTA+ adalah jenis kelamin laki-laki, tidak bekerja, berpenghasilan rendah dan tidak imunisasi BCG. (2) faktor yang kurang berisiko meningkatkan angka kejadian penyakit TB paru BTA+ adalah umur produktif, kurang gizi, berpendidikan rendah, merokok, berpengetahuan buruk, tinggal di hunian yang padat penghuni dan tidak tinggal di hunian dengan pencahayaan matahari yang baik.

Hal serupa diungkapkan oleh Rohayu dkk (2016) dalam penelitiannya terhadap masyarakat pesisir di wilayah kerja Puskesmas Kadatua Kabupaten Buton selatan yaitu (1) pengetahuan kurang memiliki risiko 2,5 kali lebih besar dibandingkan pengetahuan cukup. (2) Perokok memiliki risiko 1,33 kali lebih besar dibandingkan bukan perokok. (3) riwayat kontak risiko tinggi memiliki risiko 5 kali lebih besar dibandingkan riwayat kontak risiko rendah. (4) Kepadatan hunian tidak memenuhi syarat memiliki risiko 8 kali lebih besar dibandingkan kepadatan hunian memenuhi syarat. (5) Pencahayaan tidak memenuhi syarat memiliki risiko 9 kali lebih besar pencahayaan memenuhi syarat.

\section{Angka Kejadian TB di Kabupaten Pati Berdasarkan Umur}

Kejadian TB dapat terjadi pada semua tingkatan umur. Angka kejadian TB berdasarkan umur di Kabupaten Pati disajikan pada Gambar 4. Gambar 4 menunjukkan bahwa kejadian TB mengalami peningkatan seiring dengan bertambahnya umur. Secara umum, kejadian TB paling besar terjadi pada usia produktif. Berdasarkan kategori yang dikeluarkan oleh BPS, usia 
produktif yaitu usia 15-64 tahun. Berdasarkan penelitian Manalu (2010), penyakit TB paru paling sering ditemukan pada usia muda atau usia produktif 15-50 tahun. Hal serupa juga diungkapkan oleh Nurjana (2015) bahwa usia produktif merupakan usia dimana seseorang berada pada tahap untuk bekerja/menghasilkan sesuatu baik untuk diri sendiri maupun orang lain. $75 \%$ penderita TB paru ditemukan pada usia yang paling produktif secara ekonomi (15-49 tahun).
Selain pada usia produktif, kejadian TB juga ditemukan pada usia lebih lanjut. Hal ini disebabkan karena pada usia lebih lanjut akan rentan terhadap serangan berbagai penyakit. Manalu (2015) menyatakan bahwa dengan terjadinya transisi demografi saat ini menyebabkan usia harapan hidup lansia menjadi lebih tinggi. Usia lanjut lebih dari 55 tahun sistem imunolosis seseorang menurun, sehingga sangat rentan terhadap berbagai penyakit, termasuk penyakit TB paru.

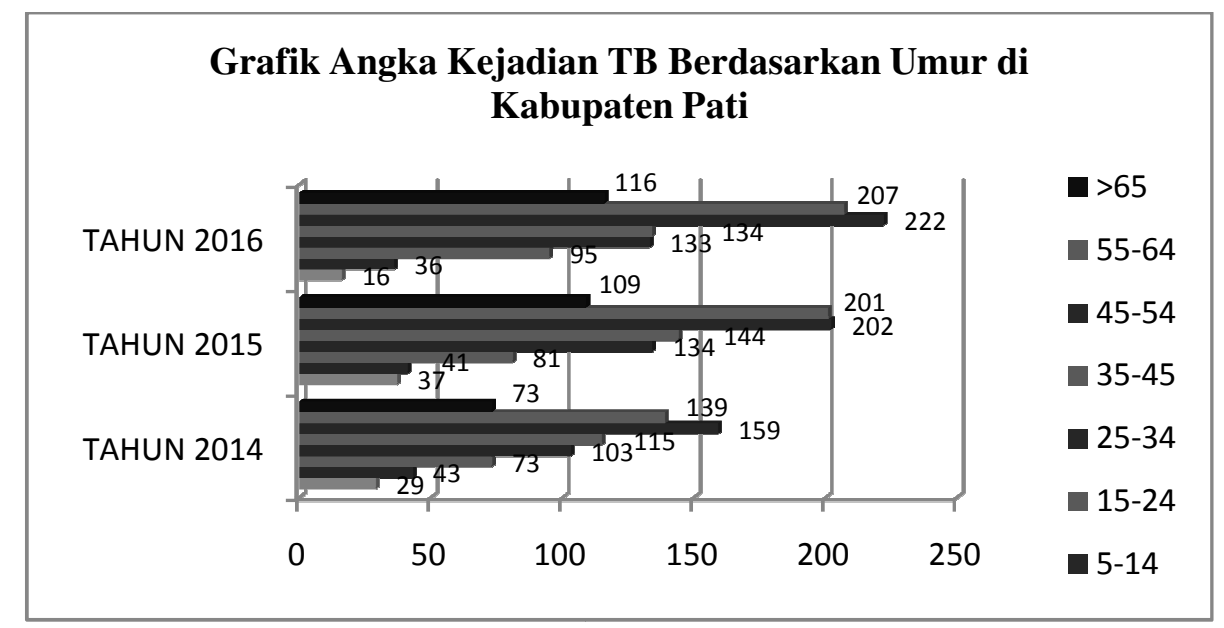

Gambar 4.

Angka Kejadian TB di Kabupaten Pati Berdasarkan Umur Tahun 2014-2016 Sumber : Dinkes Kab.Pati (2014-2016)

\section{KESIMPULAN DAN SARAN}

\section{Kesimpulan}

Kesimpulan dari hasil penelitian adalah (1) angka kejadian TB di Kabupaten Pati tahun 2014-2016 menunjukkan adanya peningkatan; (2) angka kejadian TB berdasarkan klasifikasi jenis kelamin lebih banyak ditemukan pada jenis kelamin laki-laki dan dalam kurun waktu tahun 2014-2016 menunjukkan terjadi peningkatan kejadian TB baik untuk jenis kelamin laki-laki maupun perempuan; (3) angka kejadian TB berdasarkan klasifikasi TB secara umum menunjukkan terjadi peningkatan dan mayoritas kejadian adalah TB paru BTA positif; (4) kejadian TB mengalami peningkatan seiring dengan bertambahnya umur. Secara umum, kejadian TB paling besar terjadi pada usia produktif.

\section{Saran}

Saran yang diberikan yaitu bagi dinas kesehatan Kabupaten Pati 
mendelegasikan tugas kepada Puskesmas-puskesmas di Kabupaten Pati, Rumah Sakit di Kabupaten Pati, Balai Pengobatan Penyakit Paru-paru (BP4), klinik dan dokter praktek swasta di Kabupaten pati : (1) memberikan layanan penanganan dan pengobatan pasien TB secara intensif, (2) melaksanakan sosialisasi dan promosi kesehatan kepada masyarakat tentang penyakit TB baik itu gejala, cara penularan, cara pencegahan, cara pengobatan maupun bahaya penyakit TB.

\section{DAFTAR PUSTAKA}

Barker, R. D. (2012). Clinical Tuberculosis. Medicine, 40(6), 340-345.

Darmawansyah. (2016). Beberapa Faktor Risiko Kejadian TB Paru pada Pekerja Tambang Emas Tradisional di Kabupaten Lebong. Tesis. Program Studi Magister Epidemiologi Program Pasca Sarjana. Semarang : Universitas Diponegoro.

Datulong, J. F. J., Sapulete. M. R., Kandau, G. D. (2015). Hubungan Faktor Risiko Umur, Jenis Kelamin dan Kepadatan Hunian Dengan Kejadian Penyakit TB Paru di Desa Wori Kecamatan Wori. Jurnal Kedokteran Komunitas dan Tropik, III(2), 5765.

Departemen Kesehatan Republik Indonesia. (2007). Pedoman Nasional Penanggulangann Tuberkulosis. Edisi 1 Cetakan Pertama. Jakarta.

Dinas Kesehatan Provinsi Jawa Tengah. (2017). Kebijakan dan Strategi dalam Implementasi TOSS TB di Jawa Tengah. Semarang.

Djoerban, Z., Djauzi, S. (2014). Buku Ajar Ilmu Penyakit Dalam. Edisi Ke enam Jilid 1. Jakarta: Interna Publising.

Guo, N., Marra, F., Marra, C. A. (2009). Measuring Health-Related Quality of Life in Tuberculosis : A Systematic Review. Health Qual Life Outcomes, 7(14). https://www.ncbi.nlm.nih.gov/pub med/19224645. Diakses 27 September 2017.

Kementerian Kesehatan Republik Indonesia. (2011). Pedoman Nasional Pengendalian Tuberkulosis. Jakarta : Kemenkes RI.

Kurniasari, R. A. S., Suhartono., Cahyo, K. (2012). Faktor Risiko Kejadian Tuberkulosis Paru di Kecamatan Baturetno Kabupaten Wonogiri. Media Kesehatan Masyarakat Indonesia, 11(2), 198-204.

Lawn, S. D., Zumla, A. I. (2011). Tuberculosis. Lancet, 378(9785), 57-72.

Lönnroth, K., Jaramillo, E., Williams, B. G., Dye, C. Raviglione, M. (2009). Drivers of Tuberculosis Epidemics : The Role of Risk Factors and Social Determinants. Medicine, 68(12), 2240-2246.

Manalu, H. S. P. (2015). Faktor-faktor Yang Mempengaruhi Kejadian TB Paru dan Upaya Penanggulangannya. Jurnal Ekologi Kesehatan, 9(4), 13401346. 
Meena, L. S. (2010). Survival Mechanisms of Pathogenic Mycobacterium Tuberculosis H37Rv. FEBS Journal, 277(11), 2416-2427.

Muaz, F. (2014). Faktor-faktor yang Mempengaruhi Kejadian Tuberkulosis Paru Basil Tahan Asam Positif di Puskesmas Wilayah Kecamatan Serang Kota Serang Tahun 2014. Skripsi. Program Studi Pendidikan Dokter Fakultas Kedokteran dan Ilmu Kesehatan. Jakarta : Universitas Islam Negeri Syarif Hidayatullah.

Nurjana, M. A. 2015. Faktor Risiko Terjadinya Tuberculosis Paru Usia Produktif (15-49 Tahun) di Indonesia. Media Litbangkes, 25(3), 165-170.

Purnamasari, Y. (2010). Hubungan Merokok dengan Angka Kejadian Tuberkulosis Paru di RSUD Dr. Moewardi Surakarta. Skripsi. Fakultas Kedokteran. Surakarta : Universitas Sebelas Maret.

Rab, T. (2013). Ilmu Penyakit Paru. Edisi ke Dua. Jakarta : Trans InfoMedia.

Rohayu, N., Yusran. S., Ibrahim, K. (2015). Analisis Faktor Risiko Kejadian TB Paru BTA Positif pada Masyarakat Pesisir di Wilayah Kerja Puskesmas Kadatua Kabupaten Buton Selatan Tahun 2016. JIMKESMAS, 1(3), 1-15.

Rukmini., Chatarina U. W. (2011). Faktor-faktor yang Berpengaruh Terhadap Kejadian TB Paru Dewasa di Indonesia (Analisis
Data Riset Kesehatan Dasar Tahun 2010). Buletin Penelitian Sistem Kesehatan, 14 (4), 320-331.

Saptawati, L., Mardiastuti., Kurniawati, A., Rumende, C. M. (2012). Evaluasi Metode FastPlaqueTB ${ }^{\mathrm{TM}}$ untuk Mendeteksi Mycobacterium Tuberculosis Pada Sputum di Beberapa Unit Pelayanan Kesehatan di Jakarta-Indonesia. Jurnal Tuberkulosis Indonesia, 8, 1-6.

Sivaranjini, S., Vanamail, P., Eason, J. (2010). Six Minute Walk Test in People with Tuberculosis Sequelae. Cardiopulmonary Physical Therapy Journal, 21(3), 5-10.

Talarico, S., Ijaz, K., Zhang, X., Mukasa, L. N., Zhang, L., Marrs, C. F., Cave, M. D., Bates, J. H., Yang, Z. (2011). Identification of Factors for Tuberculosis Transmission Via An Integrated Multidisciplinary Approach. Tuberculosis (Edinburgh, Scotland), 91(3), 244249.

World Health Organization. (2004). Brief Guide on Tuberculosis Control for Primary Health Care Providers. New Jersey : Medical School National Tuberculosis Center.

World Health Organization. (2009). WHO Report 2009: Global Tuberculosis Control Epidemiology, Strategy, Financing. Geneva : WHO Press. whqlibdoc.who.int/publications/ 2009/9789241563802_eng.pdf. Diakses 25 September 2017. 
World Health Organization. (2011). Global Tuberculosis Control. Geneva : World Health Organization.

Widoyono. (2008). Penyakit tropis : Epidemiologi, Penularan, Pencegahan dan Pemberantasannya. Surabaya : Erlangga

Zaman, K. (2010). Tuberculosis : A Global Helath Problem. Bangladesh : International Centre For Diarrhoeal Disease Research.

Zeana, C. El Sadr, W. (2004). The Effect of Gender on The Epidemiology, Clinical Presentation, and Management of Tuberculosis.
Principles of Gender-Specific Medicine : 938945.https://www.researchgate.net/ publication/285420646_The_Effec t_of_Gender_on_the_Epidemiolog y_Clinical_Presentation_and_Man agement_of_Tuberculosis. Diakses 28 September 2017.

\section{BIODATA PENULIS}

Dwi Murtono, lahir di Grobogan pada 11 Desember 1985. Pendidikan Sarjana Kesehatan Masyarakat di Universitas Muhammadiyah Surakarta dan Magister Epidemiologi di Universitas Diponegoro Semarang. Saat ini bekerja sebagai Epidemiolog Kesehatan Ahli Pertama di RSUD Kayen Kabupaten Pati. 